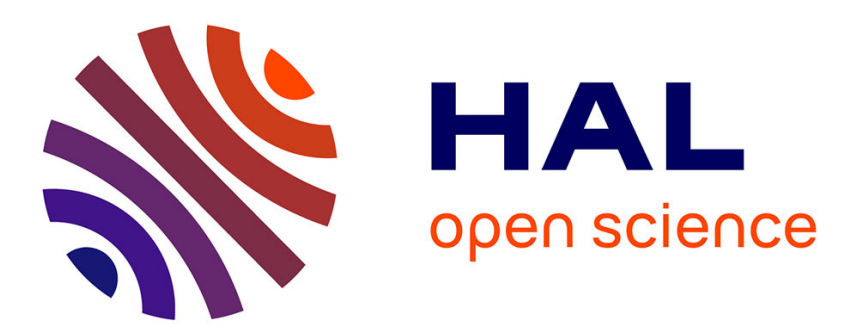

\title{
Genetic variability in biomass allocation to roots in wheat is mainly related to crop tillering dynamics and nitrogen status
}

\author{
Vincent Allard, Pierre Martre, Jacques Le Gouis
}

\section{To cite this version:}

Vincent Allard, Pierre Martre, Jacques Le Gouis. Genetic variability in biomass allocation to roots in wheat is mainly related to crop tillering dynamics and nitrogen status. European Journal of Agronomy, 2013, 46, pp.68-76. 10.1016/j.eja.2012.12.004 . hal-00759094

\section{HAL Id: hal-00759094 https://hal.science/hal-00759094}

Submitted on 30 Nov 2012

HAL is a multi-disciplinary open access archive for the deposit and dissemination of scientific research documents, whether they are published or not. The documents may come from teaching and research institutions in France or abroad, or from public or private research centers.
L'archive ouverte pluridisciplinaire HAL, est destinée au dépôt et à la diffusion de documents scientifiques de niveau recherche, publiés ou non, émanant des établissements d'enseignement et de recherche français ou étrangers, des laboratoires publics ou privés. 
1 Genetic variability in biomass allocation to roots in wheat is mainly related to crop tillering

2 dynamics and nitrogen status

3

4 Vincent Allard ${ }^{1,2}$, Pierre Martre ${ }^{1,2}$, Jacques Le Gouis ${ }^{1,2}$

5

$6{ }^{1}$ INRA, UMR 1095 Genetics, Diversity and Ecophysiology of Cereals, 5 chemin de Beaulieu,

$7 \quad$ F-63 039 Clermont-Ferrand, Cedex 2, France

8 22Université Blaise Pascal, UMR 1095 Genetics, Diversity and Ecophysiology of Cereals, F-

963177 Aubière, France

10

11 Author for correspondence:

12 Vincent Allard

13 Tel: +33473624422

$14 \quad$ Fax: +33473624457

15 Email: vincent.allard@clermont.inra.fr

16

17 
Improving arable crops Nitrogen Use Efficiency (NUE) is a major target of plant breeding. In wheat, a large part of the Nitrogen $(\mathrm{N})$ harvested in the grain originates from $\mathrm{N}$ remobilization from vegetative organs during the post-anthesis period. While $\mathrm{N}$ remobilization from aboveground organs such as leaves and stems has been extensively studied, studies about $\mathrm{N}$ remobilization from roots are scarce. The existence of genetic variability for biomass allocation to the root pool as well as for root $\mathrm{N}$ concentration and remobilization may strongly affect the $\mathrm{N}$ economy of the crop. By studying the root system of 16 elite wheat genotypes under two contrasted $\mathrm{N}$ treatments, we showed that the biomass allocation to roots was strongly related to crop tillering dynamics and $\mathrm{N}$ nutritional status. Therefore, the apparent genetic variability for biomass allocation to roots is not intrinsic, but rather a consequence of genetic variability for crop growth and $\mathrm{N}$ utilization taken as a whole. In addition, we showed here that the $\mathrm{N}$ amount potentially remobilized from roots to the grain is extremely small. Existing genetic variability for root $\mathrm{N}$ content and remobilization efficiency cannot explain observed differences in genotypes grain $\mathrm{N}$ concentration or $\mathrm{N}$ yield. These results indicate that there is little prospect for breeding strategies specifically aiming at optimizing wheat root biomass allocation and N remobilization for improving NUE and GPC for elite genotypes at least in highly productive conditions. These results nevertheless do not imply that the root compartment should be totally discarded in all breeding programs since architectural traits such as root length or distribution may impact strongly crop performance.

Wheat; gentic variability; root; NUE 


\section{Introduction}

Until very recently, productivity has been the major target of agronomical sciences. The growing demand for low input agriculture, driven both by economical and environmental considerations emphasizes now the improvement of resource use efficiency. Nitrogen $(\mathrm{N})$ fertilizers play a major role in crop productivity, but are also one of the main sources of agricultural pollution either through nitrous oxide $\left(\mathrm{N}_{2} \mathrm{O}\right)$ volatilization or nitrate $\left(\mathrm{NO}_{3^{-}}\right)$ leaching (IPCC, 2001; DECC, 2010). N fertilization represents also a major cost for farmers. Increasing $\mathrm{N}$ use efficiency (NUE) received therefore much attention in the recent years whether through improved agronomical practices (Cui et al, 2011) or plant breeding (eg Hirel et al. 2007; Foulkes et al., 2009; Gaju et al., 2011). This quest for highly efficient wheat cultivars and agronomical practices is made more complex by the fact that not only grain yield but also grain protein concentration (GPC), the major determinant of wheat end-use quality (eg Shewry 2007; Oury et al., 2010) should be improved. The involvement of $\mathrm{N}$ in both biomass accumulation and grain protein concentration determination creates a need for studying the complex interactions between carbon and $\mathrm{N}$ metabolisms that determine crop productivity and quality (Triboi and Triboi-Blondel, 2002).

In wheat, the major part of $\mathrm{N}$ uptake occurs before anthesis. After anthesis, $\mathrm{N}$ remobilization from the vegetative organs toward the growing grains is a strong determinant of both GPC and grain yield through the senescence process that alters the crop photosynthetic capacity (Borell et al., 2001; Triboi et al 2006; Bogard et al. 2011). Understanding finely $\mathrm{N}$ remobilization process is therefore a key question for the optimization of the $\mathrm{N}$ economy of wheat crops. $\mathrm{N}$ distribution and remobilization patterns in aboveground organs have received much attention in past years (e.g. Gregersen et al., 2008; Taylor et al., 2010). In particular, it was shown that the remobilization pattern of these vegetative organs follow a robust first- 
order kinetic that is independent of organ age, genotype and $\mathrm{N}$ nutrition (Bertheloot et al., 2008). Genetic variability for $\mathrm{N}$ remobilization efficiency has also been characterized (Barbotin et al 2005, Uauy et al., 2006; Kichey et al 2007) showing relatively large genetic variation for this trait and strong interaction with the environment and $\mathrm{N}$ fertilizer regimes.

Oppositely little is known about the $\mathrm{N}$ allocation and remobilization pattern in the wheat root system. In controlled conditions, wheat roots have the ability to remobilize $\mathrm{N}$ to the grain (Andersson et al., 2005) and are the last organs to senesce (Peoples and Dalling, 1988). In these conditions, $\mathrm{N}$ partitioning to the roots and redistribution of $\mathrm{N}$ from the roots to the grain may play an important role for the nitrogen budget of the whole plant (Andersson et al., 2005) since a large part (10 to $20 \%$ ) of the total plant $\mathrm{N}$ at maturity appears to remain in the roots (Andersson and Johansson, 2006). This may have several consequences since most studies occult the root compartment. First, accounting for the root compartment may affect to some extent whole plant NUE if it is associated to different shoot/root allocations (Andersson et al., 2005). Substantial genetic variation has already been observed for this trait in wheat (Siddique et al., 1990; Hoad 2001). Second, if variations in shoot/root allocation were associated to large differences in root $\mathrm{N}$ content and remobilization patterns, it may impact other agronomical traits such as grain protein concentration. The aim of this study was to analyze the $\mathrm{N}$ allocation to roots in wheat and the net $\mathrm{N}$ remobilization from roots during the postanthesis period under field conditions. A particular emphasis was put on the evaluation of the genetic variability associated with these processes. Root biomass, relative allocation and mass loss were studied on 16 bread wheat cultivars grown in the field at two $\mathrm{N}$ levels. Root $\mathrm{N}$ content and remobilization were quantified in order to evaluate the potential role of $\mathrm{N}$ remobilization from roots in the $\mathrm{N}$ economy of the crop. 


\section{Materials and Methods}

\subsection{Plant material and growing conditions}

Sixteen genotypes of winter bread wheat (Table 2) were studied in a field experiment carried out at Clermont-Ferrand, France $\left(45^{\circ} 47^{\prime} \mathrm{N}, 3^{\circ} 10^{\prime}\right.$ E, $329 \mathrm{~m}$ elevation) during the $2007-2008$ growing season. This panel of genotypes represents a large part of the genetic variability for nitrogen use efficiency and its components (Le Gouis et al., 2000; Gaju et al., 2011) and for the deviation from the negative correlation between grain yield and protein concentration (Oury et al., 2003) reported in UK and France elite germplasms. Soil characteristics $f$ are presented in Table 2. Crops were sown at a density of 250 seeds $\mathrm{m}^{-2}$ on 06 November 2007. A high (HN) and a low (LN) $\mathrm{N}$ treatments were applied. For the $\mathrm{HN}$ treatments, the rates of $\mathrm{N}$ fertilisation were determined using the balance sheet method (Rémy \& Hébert, 1977) to optimize grain yield. $\mathrm{N}$ was applied in four splits as ammonium nitrate granules $(33.5 \% \mathrm{~N})$ with $4,8,8$, and $4 \mathrm{~g}$

$\mathrm{N} \mathrm{m}^{-2}$ being applied when Rialto, which has a rate of development in the middle of the range of the sixteen cultivars used in this study (Table 2), reached growth stages (GS; Zadocks et al., 1974) GS21 (beginning tillering), GS31 (ear at 1cm), GS39 (male meiosis), and GS61 (anthesis) respectively. In the $\mathrm{LN}$ treatment, $4 \mathrm{~g} \mathrm{~N} \mathrm{~m}^{-2}$ were applied in one split when Rialto reached GS31. The experimental field was not irrigated. All other crop inputs including weed, disease and pest control, and potassium, phosphate and sulfur fertilizers, were applied at levels to prevent nutrients or weeds, diseases and pests from limiting yield. The experimental design was a split-plot in which $\mathrm{N}$ treatment was randomized on main plots, cultivars were randomized on the sub-plots and each treatment was replicated three times. Sub-plot size was $7 \times 1.5 \mathrm{~m}$ with an inter-row spacing of $0.17 \mathrm{~m}$. 
117 Plants were sampled at anthesis (GS61) and full grain maturity (GS92). When each genotype

118 reached the appropriate stage, $0.5 \mathrm{~m}^{2}$ per sub-plot was cut at ground level. The total fresh 119 mass of the samples was determined and a $25 \%$ sub-sample was randomly selected. The main 120 and secondary shoots were separated and counted. Shoots were classified as main when the 121 top of their ear was in the top $0.15 \mathrm{~m}$ layer of the canopy. Thirty main shoots were randomly 122 selected and dissected into individual leaf laminae, stems (including leaf sheaths) and ears. 123 The fresh mass of the secondary shoots of the sub-samples was determined, and sub-samples 124 of secondary shoot (20\%) were randomly selected. Their fresh mass was determined before 125 separating them into leaf laminae, stems (including leaf sheath) and ears. For both main and secondary shoots, green and dead photosynthetic (identified by their brownish colour) tissues were analysed separately.

\subsection{Root sampling}

130 Root sampling was performed with a square-shaped soil corer (height $=40 \mathrm{~cm}$, section $=18 \times$

$131 \quad 18 \mathrm{~cm}$ ). The corer was positioned on the soil, centered on a plant row and drove into the soil 132 to a depth of $30 \mathrm{~cm}$ with a sledge hammer. The soil core was then retrieved, soaked into $10 \mathrm{~L}$ 133 of water to facilitate soil disaggregation and washed abundantly with water above a $1 \mathrm{~mm}$ 134 mesh-size sieve until roots were totally free of soil.

\subsection{Plant tissues dry mass and nitrogen concentration,}

137 Lamina, stem, chaff, grains and roots dry mass (DM) of the main shoots were determined 138 after oven drying at $80^{\circ} \mathrm{C}$ for $48 \mathrm{~h}$. Samples were then ground and their total $\mathrm{N}$ concentration

139 ( $\mathrm{N}$ mass per unit dry mass) was determined with the Dumas combustion method (AOAC 
140 method $\mathrm{n}^{\circ}$ 7.024) using a FlashEA 1112 N/Protein analyser (Thermo Electron Corp.,

141 Waltham, MA, USA).

144 Several composite traits were calculated. Biomass allocation was investigated by calculating

145 the root/rhoot ratio $(\mathrm{R} / \mathrm{S})$ as follows:

$$
\mathrm{R} / \mathrm{S}=\mathrm{SDM} / \mathrm{RDM}
$$

147 where SDM is the total aboveground dry mass including leaves, stems, chaff and grain and

$148 \mathrm{RDM}$ the total root dry mass. The $\mathrm{N}$ root/shoot ratio (RN/SN) was calculated similarly as:

$$
\mathrm{RN} / \mathrm{SN}=\mathrm{RN} / \mathrm{SN}
$$

150 where $\mathrm{SN}$ and $\mathrm{RN}$ are the $\mathrm{N}$ amount in the aboveground and belowground organs respectively. Crop $\mathrm{N}$ harvest index was calculated based on shoot $\mathrm{N}$ only (NHI) or total plant $\mathrm{N}\left(\mathrm{NHI}_{\mathrm{tot}}\right)$ :

$$
\begin{aligned}
& \mathrm{NHI}=\mathrm{GN} / \mathrm{SN} * 100 \\
& \mathrm{NHItot}=\mathrm{GN} /(\mathrm{SN}+\mathrm{RN}) * 100
\end{aligned}
$$

155 Where GN is the amount of $\mathrm{N}$ in the grains.

156 In order to evaluate the efficiency of $\mathrm{N}$ assimilation in the crop, nitrogen utilisation efficiency was calculated based on shoot $\mathrm{N}$ only (NUtE) or total plant $\mathrm{N}\left(\mathrm{NUtE} \mathrm{E}_{\mathrm{tot}}\right)$ :

$$
\mathrm{NUtE}=\mathrm{GDM} / \mathrm{SN}
$$

$$
\mathrm{NUtE}_{\mathrm{tot}}=\mathrm{GDM} /(\mathrm{SN}+\mathrm{RN})
$$

160 Where GDM is the grain dry mass.

161 The amount of $\mathrm{N}$ lost by roots (NLR) during the post-anthesis period was calculated as the differences of $\mathrm{N}$ amounts in roots between anthesis $\left(\mathrm{RN}_{\text {anth }}\right)$ and maturity $\left(\mathrm{RN}_{\text {mat }}\right)$ :

$$
\mathrm{NLR}=\mathrm{RN}_{\mathrm{anth}}-\mathrm{RN}_{\text {mat }}
$$


164 The amount of $\mathrm{N}$ potentially remobilized from senescent roots $\left(\mathrm{NRR}_{0.3}\right)$ was estimated based

165 on the assumption that $\mathrm{N}$ concentration in dead root tissue was fixed at $0.3 \%$ since this value 166 was close from the lowest root N\% observed in this study:

$$
\mathrm{NRR}_{0.3}=\left(\mathrm{RDM}_{\mathrm{anth}}-\mathrm{RDM}_{\text {mat }}\right) \times\left(\mathrm{RN} \%_{\text {anth }}-0.3\right) / 100
$$

168 Where $\mathrm{RN} \%$ anth is the $\mathrm{N}$ concentration in root material at anthesis.

169 Finally the proportion of grain N remobilized from roots (PGNR) was calculated as

$170 \quad \mathrm{PGNR}=\mathrm{GN}_{\text {mat }} / \mathrm{NRR}_{0.3}$

171 The N nutrition Index (NNI) was estimated at anthesis as proposed by Justes et al. (1994).

$$
\mathrm{N}_{\mathrm{t}}=5.35 \times \mathrm{SDM}^{-0.442}
$$

173 Where $\mathrm{N}_{\mathrm{t}}$ is the critical $\mathrm{N}$ concentration (\%DM) and SDM expressed in $\mathrm{t}^{-\mathrm{ha}^{-1}}$. NNI is then

174 calculated as the ratio between actual shoot $\mathrm{N}$ concentration and $\mathrm{N}_{\mathrm{t}}$.

$$
\mathrm{NNI}=\mathrm{SN} \% / \mathrm{N}_{\mathrm{t}}
$$

\section{Results}

\subsection{Climate}

178 The first part of the crop cycle occurred under relatively dry conditions (Fig. 1). During the

179 September-February period rainfall was about $30 \%$ below the 20 -year average for the same 180 period. Oppositely the following part of the cycle occurred under extremely wet conditions.

181 From March to July rainfall reached $390 \mathrm{~mm}$ representing a 40\% excess compared to the 20-

182 year average. Consequently the whole post-anthesis period was characterized by an absence 183 of water limitation.

\subsection{Crop structure at anthesis}

186 The genotypes used in the present experiment exhibited a large variation in term of 187 developmental rate. Anthesis date varied from May $19^{\text {th }}$ (Récital) to June $4^{\text {th }}$ (Beaver and 
188 Consort; Table 2). Tiller number at anthesis was affected by $\mathrm{N}$ treatment $(\mathrm{P}=0.048)$ but no genotype effect was found (Table 2). On average, tiller number at anthesis was 442 and 654 tiller $\mathrm{m}^{-2}$ under $\mathrm{LN}$ and $\mathrm{HN}$, respectively. At anthesis, SDM was strongly affected by $\mathrm{N}$ treatment with an $18 \%$ increase under $\mathrm{HN}$ compared to $\mathrm{LN}$ averaged across all genotypes. Statistically significant differences between genotypes were also measured. In particular,

193 Récital and Renan, the two earliest genotypes, had high anthesis SDM under both N 194 treatments. Comparatively RDM was not affected by $\mathrm{N}$ treatment with $190 \mathrm{~g} \mathrm{DM} \mathrm{m}^{-2}$ on average over all combinations (Table 2). Genotypic effect was particularly strong with three genotypes having low RDM under both $\mathrm{N}$ treatments (Arche, CF99102 and CF 9107). No correlation was found between SDM and RDM at anthesis (data not shown) with $\mathrm{r}^{2}$ of 0.001 and 0.02 under LN and $\mathrm{HN}$, respectively. RDM was strongly and positively associated with tiller number (Fig. 2) with about $50 \%$ of the RDM variation explained by tiller number under both $\mathrm{N}$ treatments. The slope of the regression for $\mathrm{LN}$ and $\mathrm{HN}$ treatments were not statistically different (common slope: $0.22 \mathrm{gDM}$ tiller $^{-1}$ ) but the intercept was significantly lower under HN than LN. Comparatively, tiller number did not explain SDM at anthesis (Fig.2; $\mathrm{r}^{2}=0.004$ and 0.02 under LN and HN, respectively). The allocation between shoot and root of both DM (Fig. 3) and N were correlated with crop $\mathrm{N}$ status but only under LN. Under LN, R/S ratio varied between 0.18 and 0.30 while NNI varied between 0.38 and 0.55 (Fig. 3), the latter values typically found under strong $\mathrm{N}$ restrictions. The predictive power of NNI was even stronger for the $\mathrm{N}$ allocation with $\mathrm{RN} / \mathrm{SN}$ values ranging between 0.07 and 0.13 (data 208 not shown). Both relations were poorly explicative under HN (Fig. 3). This was particularly 209 caused by four outliers (genotypes Beaver, Rialto, Savannah and Soissons) with high 210 allocation of $\mathrm{DM}$ and $\mathrm{N}$ to roots. These outliers were not explained by relatively higher 211 variation coefficients than other genotypes (data not shown). If these outliers are removed, 
average R/S for the 12 remaining genotypes for $\mathrm{HN}$ was 0.19 and RN/SN was 0.08 . Both

213 values were similar to the lower range of the values observed for LN (Fig. 3).

214 RDM variation during the post-anthesis period was negatively correlated with RDM at 215 anthesis under both $\mathrm{N}$ treatments (Fig. 4, $\mathrm{r}^{2}=0.38$ and 0.67 under LN and HN respectively) 216 and ranged from $-5 \%$ to $-54 \%$. The proportional loss of belowground biomass increased with 217 the initial belowground biomass present at anthesis.

\subsection{Nitrogen remobilization from the belowground compartment and effects on nitrogen} allocation calculations

NHI at anthesis was both under strong $\mathrm{N}$ treatment and genotype effects (Table 3). On average over genotypes NHI equaled 79 and $72 \%$ under $\mathrm{LN}$ and $\mathrm{HN}$, respectively. Accounting for belowground $\mathrm{N}$ in the calculation led to an about 3 percent point decrease in the calculated $\mathrm{NHI}_{\text {tot }}$. Nevertheless this did not impact significantly genotypes ranking for this trait. Spearman's rank test gave correlation Rs values of 0.83 and 0.97 for $\mathrm{LN}$ and HN, respectively, indicating strong rank correlations between the two calculations. Results were equivalent for NUtE calculations with a small impact of accounting for belowground $\mathrm{N}$ pool. $\mathrm{NUtE}_{\text {tot }}$ was on average 1.7 percent point lower than NUtE. Again this has no impact on genotypes ranking (Rs values of 0.96 and 0.98 ) under LN and HN, respectively. Calculation of $\mathrm{N}$ potentially lost by roots during the post anthesis period (NLR) indicated that only a small

$231 \mathrm{~N}$ amount was lost as senesced material or remobilized during this period. The largest part of 232 this $\mathrm{N}$ amount was caused by a decreased in $\mathrm{RDM}$ and not by a decrease in remaining 233 biomass decrease in $\mathrm{N}$ concentration. Indeed, RN\% variation during post anthesis under $\mathrm{LN}$ 234 was nil (0.41\% at both anthesis and maturity) and only marginal under $\mathrm{HN}(0.83$ and 0.79 at 235 anthesis and maturity, respectively). Calculating potentially remobilized $\mathrm{N}$ from senesced 236 roots is hazardous since the $\mathrm{N}$ concentration of senesced root material was not measured and 
may vary with time, type of roots, treatment and genotype. Nevertheless, $\mathrm{N}$ remobilization

238 from roots $\left(\mathrm{NRR}_{0.3}\right)$ was estimated based on a putative $\mathrm{N}$ concentration in the senesced root 239 material of $0.3 \%$, a value close from the lowest root $\mathrm{N}$ concentration observed in the present 240 experiment but much lower than reported values for dead fine roots (Gordon and Jackson, 241 2000). Even based on the assumption of a $0.3 \% \mathrm{~N}$ in dead roots, extremely small amount of 242 potentially remobilized $\mathrm{N}$ from roots were calculated. $\mathrm{NRR}_{0.3}$ values were on average 0.1 and $2430.4 \mathrm{gN} \mathrm{m}^{-2}$ for $\mathrm{LN}$ and $\mathrm{HN}$, respectively, corresponding to 0.8 and $2.3 \%$ of the total grain $\mathrm{N}$ at 244 maturity. Genetic variation observed for both the quantity and the proportion of $\mathrm{N}$ 245 remobilized from roots were not correlated with any of the traits of interest such as grain $\mathrm{N}$ 246 quantity or concentration (data not shown). In addition remobilization efficiency of the 247 belowground plant material was not related whatsoever with remobilization efficiency of 248 aboveground vegetative organs.

\section{Discussion}

251 The aim of this study was to analyze the potential impact of the belowground compartment on 252 the $\mathrm{N}$ economy of wheat. Based on previous results in controlled conditions showing that the $253 \mathrm{~N}$ economy of the whole plant was affected to a great extent by the $\mathrm{N}$ amount in the roots 254 (Andersson et al., 2005), our main objective was to test, under field conditions it the genetic 255 variability associated with $\mathrm{N}$ remobilized from roots was detectable. Indeed, large genetic 256 variation associated with this process might strongly impact the assessment of the genetic 257 diversity of agronomical traits of interest such as NUE, post-anthesis $\mathrm{N}$ uptake and grain N. It 258 is clear that data obtained in a single environment cannot reveal the full extent of genetic 259 variation among a set of genotypes. However, this information can help determine if 260 putatively observed genetic variability relies on intrinsic genetic differences of the root 
compartment or if these differences follow a generic response function to traits obtained at the whole plant level.

\subsection{Root sampling methodology}

265

In the present experiment root biomass was only sampled in the $0-30 \mathrm{~cm}$ horizon. Clearly the full root biomass was not harvested by this method since the maximum rooting depth was evaluated to $90 \mathrm{~cm}$ at the experimental site. This would clearly be a strong limitation if the objective was to compare genotypes in term of functional processes such as water and $\mathrm{N}$ extraction capacity. Here, the key aspect was to retrieve a large proportion of the total root biomass to assess differences of biomass and nitrogen allocation pattern between genotypes. Kätterer et al. (1993) studied the root biomass of a winter wheat genotype under four management treatments including dry and irrigated crops. On average, after anthesis about $85 \%$ of the root biomass was found in the top $30 \mathrm{~cm}$ horizon. This proportion tended to increase in the well irrigated treatment. Sidique et al. (1990) also observed very high proportion of the total root biomass in the first $30 \mathrm{~cm}$. A root dry matter profile was available for three genotypes and showed that more than $90 \%$ of the total root biomass was in this horizon. Similar figures can be found in Wechsung et al. (1999). Xue et al. (2003) reported lower proportion of root biomass (about $60 \%$ ) in the first $30 \mathrm{~cm}$, but in a soil with a maximum rooting depth of $2 \mathrm{~m}$ thus more than twice as deep as our soil. We therefore believe that the sampling method used in the present experiment allowed harvesting a very significant proportion of the total root biomass and that it is very unlikely that significant bias would hamper genotype comparisons. Kätterer et al. (1993) reported roots biomass values at anthesis of $92 \mathrm{~g} \mathrm{~m}^{-2}$ while values presented by Siddique et al. (1990) at the same developmental stage are three times higher $\left(310 \mathrm{~g} \mathrm{DM} \mathrm{m}^{-2}\right)$. With average values of about $200 \mathrm{~g} \mathrm{DM} \mathrm{m}^{-2}$ the values 
of the present study tend to confirm that the sampled biomass is representative of the whole 286 soil profile.

The present data clearly shows the effect of the genetic differences in tiller numbers on both root biomass and allocation. Comparatively, both aboveground biomass and yield were independent of tiller number in the present study. Tiller number optimization has been identified as a potential candidate trait for yield increase (Reynolds et al., 2009). Under extremely limiting conditions such as strong terminal drought, low tiller number may be a

294 promising trait for water economy and final grain yield (Dugan et al., 2005; Munns and 295 Richards, 2007). The introduction of a reduced tillering (tin) gene in wheat lines has nevertheless been shown to have extremely contrasted effects on yield depending on the environment and genetic background but with a tendency towards grain yield reduction 298 (Mitchell et al., 2012). In the present growing conditions, with elite material, it seems that the 299 observed genetic variations in tiller number is only a phenotypic expression of the strong 300 phenotypic plasticity of wheat, a crop that is able to express yield in a range of ways through 301 strong compensations between yield components (Lawless et al., 2005; Sinclair and Jamieson, 302 2008). In particular the tiller size/density compensation process, well characterized in 303 perennial grasses (Matthews, 1996) seems to have operated in our conditions. Nodal root 304 emission is strongly synchronized with leaf and tiller production (Klepper et al 1984). This 305 coordination does not necessarily induce a metric relationship between tiller number and root 306 biomass. Individual root can vary in diameter, length or density and have a specific branching 307 pattern that potentially breaks this relationship. In addition, low tillering can be seen as a 308 possibility for plants to allocate more resources towards root development (Duggan et al., 
2005). Nevertheless, the data presented here show that the tillering dynamic of the crop has a

310 strong influence on root biomass at anthesis.

313 A second strong determinant of biomass allocation to roots at anthesis is the crop nitrogen

314 status. The effect of the plant nitrogen status on the R/S ratio of plant has received much

315 attention in particular for modeling purpose (Hilbert, 1990; Gleeson, 1993; Thornley, 1995;

316 1998; Agren and Franklin, 2003) and clearly demonstrated that the R/S decreases with

317 increasing $\mathrm{N}$ supply. These models use plant N concentration (Franklin and Agren, 2003) or

318 C, N availability (Thornley, 1995) to predict biomass allocation and are based on the

319 hypothesis that biomass allocation is strongly controlled at the plant level and optimized in

320 relation to the availability of $\mathrm{C}$ and $\mathrm{N}$. In our study, NNI was the best predictive variable for

321 R/S. The nitrogen nutrition index as described in Gastal and Lemaire (2002) allows to

322 quantify the $\mathrm{N}$ status of the crop dynamically; i.e. accounting for the decreasing crop $\mathrm{N}$

323 demand as crop gets larger (Gastal and Lemaire, 2002). Therefore, optimal crop relative

324 growth rate is attained for a crop $\mathrm{N}$ concentration, called critical $\mathrm{N}$ concentration that

325 decreases following a power function of crop biomass. NNI derives from a comparison

326 between actual crop $\mathrm{N}$ concentration and critical $\mathrm{N}$ concentration at the observed biomass and

327 allows the $\mathrm{N}$ status of the crop to be quantified over development and also to compare $\mathrm{N}$

328 status of crops of different biomass.

330 Modeling analysis clearly showed that functional equilibrium approaches predicting R/S in 331 term of $\mathrm{C}$ and $\mathrm{C}$ co-limitation was not valid for extreme conditions of high and low $\mathrm{N}$ 332 availability (Agren and Flanklin, 2003). This can be related to the apparent saturation of the $333 \mathrm{R} / \mathrm{S}$ response to NNI for high NNI values. Indeed in the present study R/S reached a minimal 
$\mathrm{R} /$ value of about 0.2 in the $\mathrm{HN}$ treatment. A possible explanation for this saturation relies on

335 the positive correlation between tiller density and R/S observed here caused by the strong coordination between tiller and root dynamic (Hoad et al., 2001) which may lead to a minimal $\mathrm{R} / \mathrm{S}$ under given environmental conditions.

338 Based on the strong association observed between root biomass and crop tillering dynamic on

339 the one hand and allocation and crop $\mathrm{N}$ status on the second hand, we believe that the 340 observed genetic variability for biomass allocation to roots (Table 2), is a consequence of 341 genetic variability for crop growth and $\mathrm{N}$ utilization taken as a whole rather than an intrinsic 342 variability for biomass allocation to roots.

344 In term of potential nutrient remobilization to the grain during the post anthesis period, it is 345 also important to assess the biomass variation of the root pool during this period. In wheat 346 decrease in root mass after anthesis is generally observed due to a root death rate exceeding 347 root production rate (Kätterer et al., 1993; Steingrobe et al., 2001). This is a common feature 348 observed in annual plants for which the developing grain is a strong competitive sink for the 349 carbon resource (Eissenstadt and Yanai, 1997) leading to a strong root length decline after 350 flowering in wheat (Box and Johnson, 1987 in Eissenstadt and Yanai, 1997). In the present study we observed a strong negative correlation between root mass loss during the post352 anthesis period and root biomass at anthesis. In other words, plants with high root biomass at 353 anthesis tend to loose a greater proportion of this biomass. A possible explanation relies on 354 the much shorter life span of fine roots compared to larger roots (Eissenstadt et al., 2000). 355 Indeed a large part of the root biomass variability may be associated with branching variability leading to a greater proportion of fine roots in plants with high root biomass. No root separation by class size could be performed in the present study therefore the causal explanation of this process remains putative. Nevertheless, the key aspect is that the apparent 
genotypic variation associated with root biomass loss follows general responses and probably

360 do not mean a genetic variability for root longevity stricto sensu.

\subsection{Root nitrogen content and remobilization}

363

364

In the present study no attempt was made to differentiate live from dead roots in the sampled material. Therefore the analyzed material is a mixture of roots differing in age and state. Nevertheless based on this coarse dataset it seems clear that net $\mathrm{N}$ remobilization from roots during the post-flowering period in wheat grown in the field is a marginal process. First, $\mathrm{N}$ concentration in the sampled root materials did not vary between anthesis and maturity (Table 3). Comparatively, other vegetative organs are a net source of $\mathrm{N}$ for the developing grain and remobilize about $70 \%$ of the $\mathrm{N}$ present at anthesis (e.g. Gaju et al., 2011). The remobilization pattern of these vegetative organs follows a robust first-order kinetics independent of organ age, genotype and $\mathrm{N}$ nutrition (Bertheloot et al., 2008). Second, the estimated potential $\mathrm{N}$ remobilization from dead roots represents less than $3 \%$ of the total grain $\mathrm{N}$ at maturity. Our estimate of remobilized $\mathrm{N}$ is in addition probably overestimated since past studies focusing specifically on nutrient remobilization from dying fine roots tended to show that $\mathrm{N}$ concentration did not vary between live and dead roots material implying little if no $\mathrm{N}$ retranslocation from senescing roots (Gordon and Jackson, 2008). Based on an experiment in hydroponic conditions, Andersson and Johansson (2006) observed that $\mathrm{N}$ amount in the root at maturity was $10-20 \%$ of total plant $\mathrm{N}$ thus potentially affecting NUE calculations. Here we clearly show that under field conditions $\mathrm{N}$ amount in the roots is about $4 \%$ of total plant $\mathrm{N}$ and affects only marginally calculated variables such as NHI or NutE with in particular no effect on genotype ranking for these variables. In addition no correlation between root $\mathrm{N}$ concentration or estimated amount of $\mathrm{N}$ remobilized from roots and agronomic variables of interest were found. Quantitatively speaking, the amount of $\mathrm{N}$ potentially remobilized from 
roots, in spite of its probable over estimation in the present study cannot affect significantly

385 the amount of $\mathrm{N}$ in the grain. Clearly, the observed genetic variation for grain $\mathrm{N}$ content is not 386 likely to be determined by variations in the root $\mathrm{N}$ pool.

\section{Conclusions}

389 This experiment provided strong indications that the apparent genetic variability existing for

390 wheat root biomass and allocation is driven by crop growth pattern rather than root growth

391 variability per se. Similarly, root loss during the post-anthesis period appeared to be largely

392 driven by root biomass at anthesis. More generally root biomass dynamics seems to be

393 determined to great extent by the crop status at anthesis. There seems to be little prospect for a

394 further exploration of root biomass genetic variability that is independent of crop response.

395 Given the relatively small proportion of $\mathrm{N}$ in the roots and the apparent low $\mathrm{N}$ remobilization

396 from this pool to the grain, taking into account roots in the determination of $\mathrm{N}$ related traits

397 such as NUE appears of little interest. In particular, genotype ranking for this trait is not

398 affected by the accounting or not of this generally ignored $\mathrm{N}$ compartment. Of course, root

399 architectural traits such as total root length and root vertical distribution may be of major

400 importance for crop $\mathrm{N}$, water acquisition and adaptation. Observed genetic variability for

401 such traits may be strong determinants of wheat genotypes performance in particular in

402 limited environment (Manshadi et al., 2010), but this was beyond the scope of the present 403 study.

404 


\section{Acknowledgements}

407 Bernard Bonnemoy build the soil corer and did all soil sampling and root washing. Joelle

Messaoud did all plant sampling, biometric measurements and elemental analysis. The authors also want to thank Nicole Allard for her technical participation to this experiment.

\section{References}

Ågren, G.I., and Franklin, O., 2003. Root:Shoot Ratios, Optimization and Nitrogen Productivity. Ann.Bot. 92, $795-800$. Spring Wheat Cultivars. J. Agron. Crop Sci. 192, 121-131.

Andersson, A., Johansson, E., and Oscarson, P., 2005. Nitrogen redistribution from the roots in post-anthesis plants of spring wheat. Plant Soil 269, 321-332.

Barbottin, A., Lecomte, C., Bouchard, C., and Jeuffroy, M.-H., 2005. Nitrogen Remobilization during Grain Filling in Wheat. Crop Sci. 45, 1141.

Bertheloot, J., Martre, P., and Andrieu, B., 2008. Dynamics of Light and Nitrogen Distribution during Grain Filling within Wheat Canopy. Plant Physiol.148, 17071720.

Borrell, A., Hammer, G., and van Oosterom, E., 2001. Stay-green: A consequence of the balance between supply and demand for nitrogen during grain filling? Ann. Appl. Biol. 138, 91-95.

Cui, Z., Zhang, F., Chen, X., Li, F., and Tong, Y., 2011. Using In-Season Nitrogen Management and Wheat Cultivars to Improve Nitrogen Use Efficiency. Soil Sci. Soc. Am. J. 75, 976. 
Duggan, B.L., Richards, R.A., Van Herwaarden, A.F., and Fettell, N.A., Agronomic evaluation of a tiller inhibition gene (tin) in wheat. I. Effect on yield, yield components, and grain protein. Aust. J. Agric. Res. 56, 169-178.

Eissenstat, D.M., Wells, C.E., Yanai, R.D., and Whitbeck, J.L., 2000. Building roots in a changing environment: implications for root longevity. New Phytol. 147, 33-42.

Eissenstat, D.M., and Yanai, R.D., 1997. The Ecology of Root Lifespan. Adv. Ecol. Res. 27, $2-60$.

Gaju, O., Allard, V., Martre, P., Snape, J.W., Heumez, E., LeGouis, J., Moreau, D., Bogard, M., Griffiths, S., Orford, S., et al., 2011. Identification of traits to improve the nitrogen-use efficiency of wheat genotypes. Field Crops Res. 123, 139-152.

Gastal, F., and Lemaire, G., 2002. N uptake and distribution in crops: an agronomical and ecophysiological perspective. J. Exp. Bot. 53, 789-799.

Gleeson, S.K., 1993. Optimization of Tissue Nitrogen and Root-Shoot Allocation. Ann. Bot. $71,23-31$.

Gordon, W.S., and Jackson, R.B., 2000. Nutrient Concentrations in Fine Roots. Ecology 81, 275-280.

Le Gouis, J., Béghin, D., Heumez, E., and Pluchard, P., 2000. Genetic differences for nitrogen uptake and nitrogen utilisation efficiencies in winter wheat. Eur. J. Agron. 12, 163173.

449 Gregersen, P.L., Holm, P.B., and Krupinska, K., 2008. Leaf senescence and nutrient remobilisation in barley and wheat. Plant Biol. 10, 37-49.

451 Hilbert, D.W., 1990. Optimization of Plant Root: Shoot Ratios and Internal Nitrogen 452 Concentration. Ann. Bot. 66, 91 -99. 
Hirel, B., Le Gouis, J., Ney, B., and Gallais, A., 2007. The challenge of improving nitrogen use efficiency in crop plants: towards a more central role for genetic variability and quantitative genetics within integrated approaches. J. Exp.Bot. 58, 2369 -2387.

Hoad, S.P., Russell, G., Lucas, M.E., and Bingham, I.J., 2001. The management of wheat, barley, and oat root systems. Adv. Agron. 74, 193-246.

IPCC, 2001: Climate Change 2001: The Scientific Basis. Contribution of Working Group I to the Third Assessment Report of the Intergovernmental Panel on Climate Change [Houghton, J.T., Ding, Y., Griggs, D.J., Noguer, M., van der Linden, P.J., Dai, X., Maskell, K. and C.A. Johnson (Eds.)]. Cambridge University Press, Cambridge, United Kingdom and New York, NY, USA, 881pp.

Justes, E., Mary, B., Meynard, J.-M., Machet, J.-M., and Thelier-Huche, L., 1994. Determination of a Critical Nitrogen Dilution Curve for Winter Wheat Crops. Ann. Bot. 74, 397-407.

Kätterer, T., Hansson, A.-C., and Andrén, O., 1993. Wheat root biomass and nitrogen dynamics — effects of daily irrigation and fertilization. Plant Soil 151, 21-30.

Kichey, T., Hirel, B., Heumez, E., Dubois, F., and Le Gouis, J., 2007. In winter wheat (Triticum aestivum L.), post-anthesis nitrogen uptake and remobilisation to the grain correlates with agronomic traits and nitrogen physiological markers. Field Crops Res. 102, 22-32.

Klepper, B., Belford, R.K., and Rickman, R.W., 1984. Root and Shoot Development in Winter Wheat. Agron. J. 76, 117.

Lawless, C., Semenov, M.A., and Jamieson, P.D., 2005. A wheat canopy model linking leaf area and phenology. Eur. J. Agron. 22, 19-32. 
Manschadi, A.M., Christopher, J.T., Hammer, G.L., Devoil, P., 2010. Experimental and modelling studies of drought-adaptive root architectural traits in wheat (Triticum aestivum L.). Plant Biosystems 144, 458-462.

Matthew, C., 1996. Seasonal patterns of root, tiller and leaf production in a Grasslands Ruanui ryegrass sward. In Proceedings of the New Zealand Grassland Association, pp. 73-76.

Mitchell, J.H., Chapman, S.C., Rebetzke, G.J., Bonnett, D.G., Fukai, S., 2012. Evaluation of a reduced-tillering (tin) gene in wheat lines grown across different production environments. Crop. Pasture Sci. 63, 128-141.

Munns, R., and Richards, R.A., Recent Advances in Breeding Wheat for Drought and Salt Stresses, in: Jenks, M.A. , Hasegawa, P.M., S.M. Jain (Eds.), Advances in Molecular Breeding Toward Drought and Salt Tolerant Crops, Springer Netherlands, Dordrecht, pp. 565-585.

Oury F.X., Berard P., Brancourt-Hulmel M., Depatureaux C., Doussinault G., Galic N., Giraud A., Heumez E., Lecomte C., Pluchard P., Rolland B., Rousset M. and Trottet M. - Yield and grain protein concentration in bread wheat: a review and a study of multi-annual data from a French breeding program [Triticum aestivum L.]. J. Gen. Breed. 57, 59-68.

Oury, F.-X., Chiron, H., Faye, A., Gardet, O., Giraud, A., Heumez, E., Rolland, B., Rousset, M., Trottet, M., Charmet, G., et al., 2009. The prediction of bread wheat quality: joint use of the phenotypic information brought by technological tests and the genetic information brought by HMW and LMW glutenin subunits. Euphytica 171, 87-109. 
Palta, J.A., Fillery, I.R.P., and Rebetzke, G.J., 2007. Restricted-tillering wheat does not lead to greater investment in roots and early nitrogen uptake. Field Crops Res.104, 5259.

Peoples, M.B., Dalling, M.S., 1988. The interplay between proteolysis and amino acid metabolism during senescence and nitrogen reallocation, in Nodden, L.D., Leopold, A.C. (Eds.), Senescence and Aging in Plants. Academic Press, New York, pp. 182-217.

Rémi, J., and Hébert, J., 1977. Le devenir des engrais dans le sol. Compte Rendu De l'Académie d'Agriculture De France 63, 700-710.

Reynolds, M., Foulkes, M.J., Slafer, G.A., Berry, P., Parry, M.A.J., Snape, J.W., and Angus, W.J., 2009. Raising yield potential in wheat. J. Exp. Bot. 60, 1899 -1918.

Rickman, R.W., Klepper, B., and Belford, R.K., 1984. Root and Shoot Development in Winter Wheat. Agron. J. 76, 117-122.

Shewry, P.R., 2007. Improving the protein content and composition of cereal grain. J. Cereal Sci. 46, 239-250.

Siddique, K.H.M., Belford, R.K., and Tennant, D., 1990. Root:shoot ratios of old and modern, tall and semi-dwarf wheats in a mediterranean environment. Plant Soil 121, 89-98.

Sinclair, T.R., and Jamieson, P.D., 2008. Yield and grain number of wheat: A correlation or causal relationship?: Authors' response to "The importance of grain or kernel number in wheat: A reply to Sinclair and Jamieson" by R.A. Fischer. Field Crops Res. 105, 22-26.

Taylor, L., Nunes- Nesi, A., Parsley, K., Leiss, A., Leach, G., Coates, S., Wingler, A., Fernie, A.R., and Hibberd, J.M., 2010. Cytosolic pyruvate,orthophosphate dikinase functions in nitrogen remobilization during leaf senescence and limits individual seed growth and nitrogen content. Plant J. 62, 641-652. 
Thornley, J.H.M., 1995. Shoot: Root Allocation with Respect to C, N and P: an Investigation and Comparison of Resistance and Teleonomic Models. Ann. Bot. 75, 391 - 405.

Triboi, E., Martre, P., Girousse, C., Ravel, C., and Triboi-Blondel, A.-M., 2006. Unravelling environmental and genetic relationships between grain yield and nitrogen concentration for wheat. Eur. J. Agron. 25, 108-118.

Triboi, E., and Triboi-Blondel, A.-M., 2002. Productivity and grain or seed composition: a new approach to an old problem—invited paper. Eur. J. Agron. 16, 163-186.

Uauy, C., Brevis, J.C., and Dubcovsky, J., 2006. The high grain protein content gene Gpc-B1 accelerates senescence and has pleiotropic effects on protein content in wheat. J. Exp. Bot. 57, 2785-2794.

Wechsung, G., Wechsung, F., Wall, G.W., Adamsen, F.J., Kimball, B.A., Pinter JR., P.J., Lamorte, R.L., Garcia, R.L., and Kartschall, T., 1999. The effects of free-air CO2 enrichment and soil water availability on spatial and seasonal patterns of wheat root growth. Global Change Biol. 5, 519-529.

Xue, Q., Zhu, Z., Musick, J.T., Stewart, B.A., and Dusek, D.A., 2003. Root growth and water uptake in winter wheat under deficit irrigation. Plant Soil 257, 151-161.

Zadoks, J.C., Chang, T.T., and Konzak, C.F., 1974. A decimal code for the growth stages of cereals. Weed Res. 14, 415-421. 


\section{$544 \quad$ Figures captions}

545 Figure 1: Monthly mean temperatures during the growing season (closed circles) and 546 averaged over the 1990-2008 period (open circles), monthly cumulative rainfall during the 547 growing season (grey bars) and averaged over the 1990-2008 period (open dashed bars) at 548 Clermont-Ferrand. The letters indicate sowing (S), nitrogen applications for the HN and LN 549 treatments, and the periods covering the flowering $(\mathrm{F})$ and the maturity $(\mathrm{M})$ samplings.

551 Figure 2: Relations between tiller density and (A) root dry mass or (B) shoot dry mass at 552 anthesis under LN (open circles) and HN full black circles) treatments. Numbers between 1 553 and 16 refer to genotype code (see table 2 ).

555 Figure 3: Relation between (A) crop nitrogen nutrition index (NNI), (B) tiller density at anthesis and Root to shoot ratio at anthesis (R/S) under LN (open circles) and HN full black circles) treatments. Numbers between 1 and 16 refer to genotype code (see table 2).

Figure 4 : Relation between belowground dry mass at anthesis and below ground dry mass variation between anthesis and maturity under LN (open circles) and HN full black circles) treatments. Numbers between 1 and 16 refers to genotype code (see table 2). 


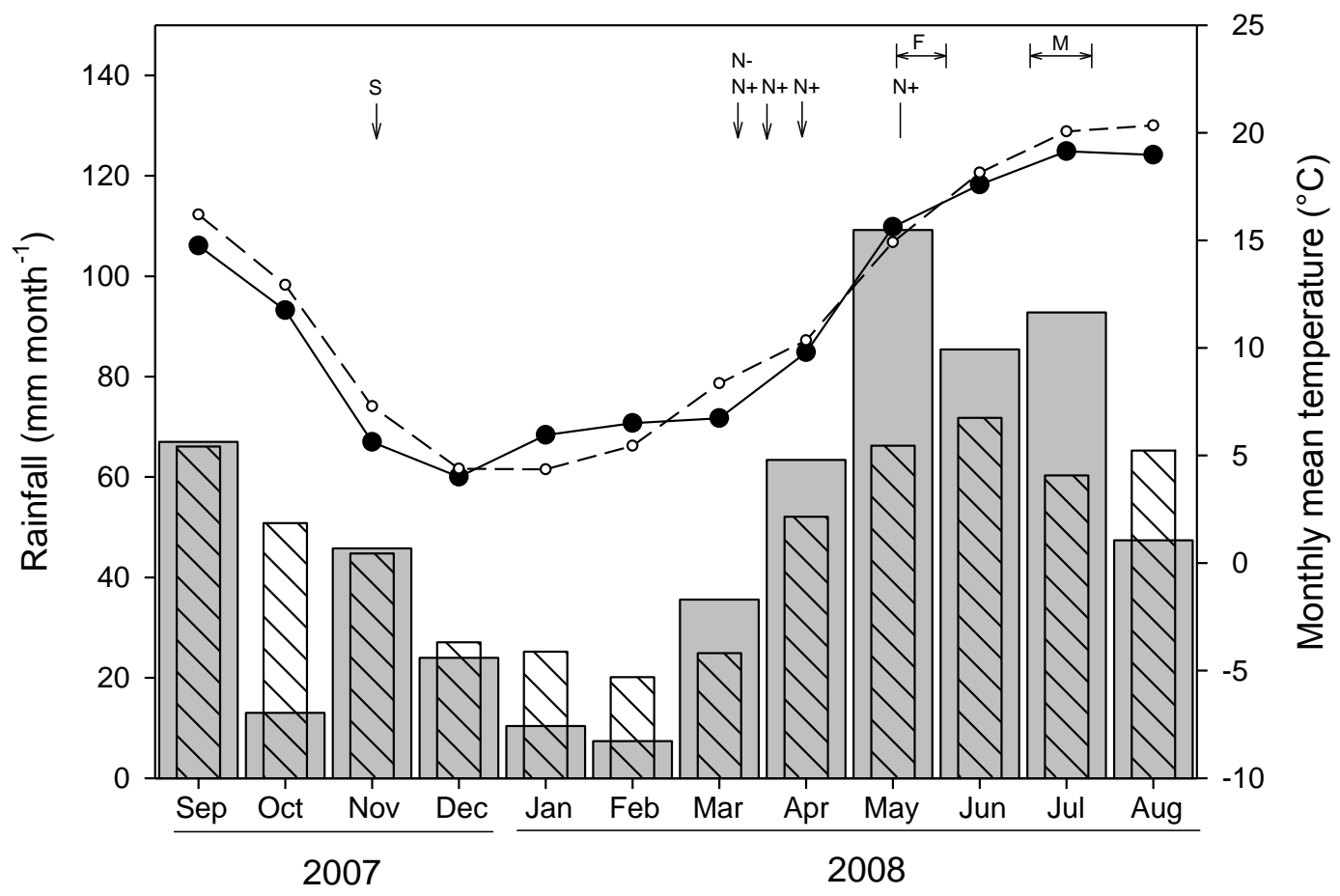

$571 \quad$ Figure 1 

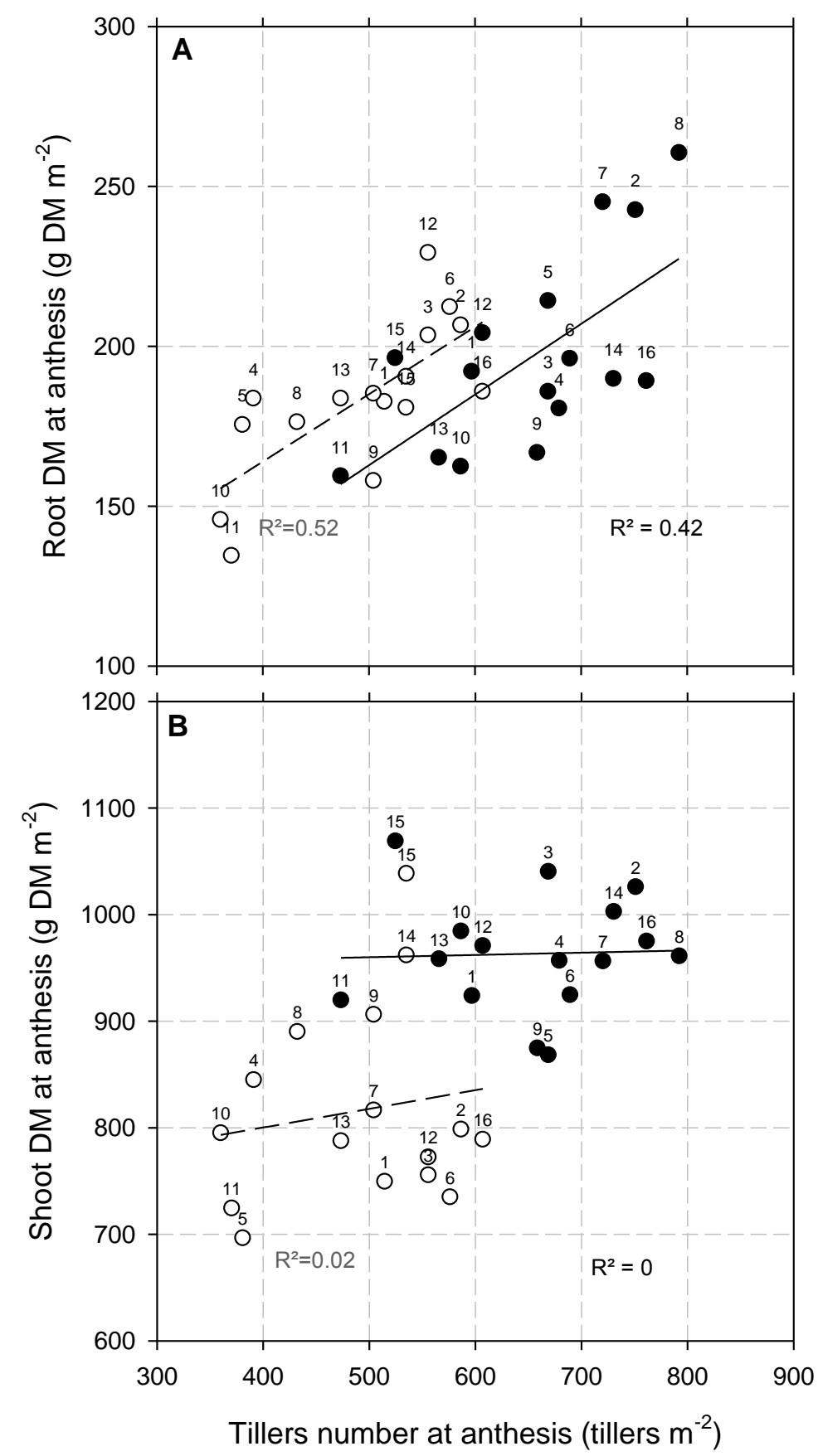

572

\section{$573 \quad$ Figure 2}

574 

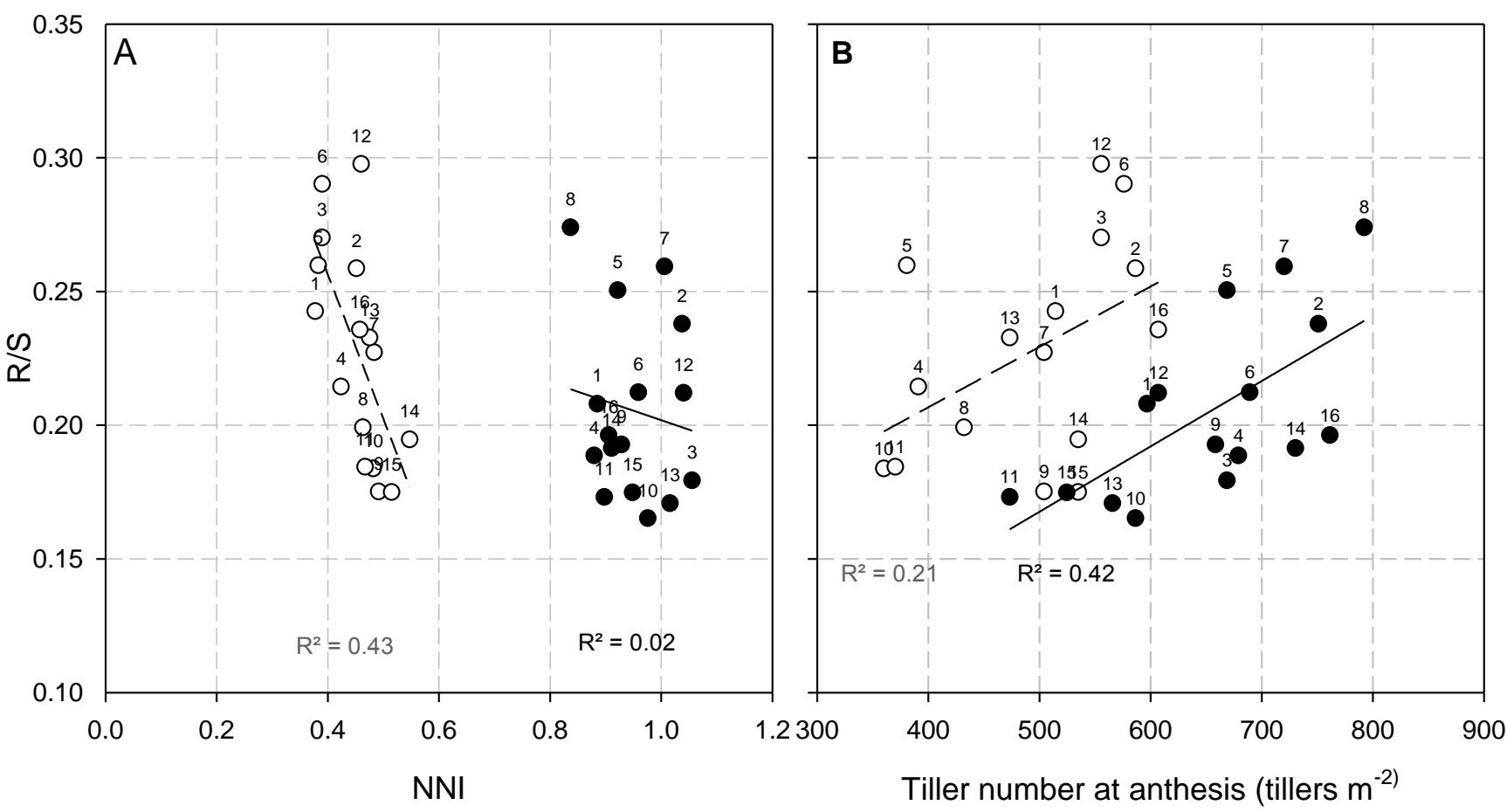

577

$578 \quad$ Figure 3 


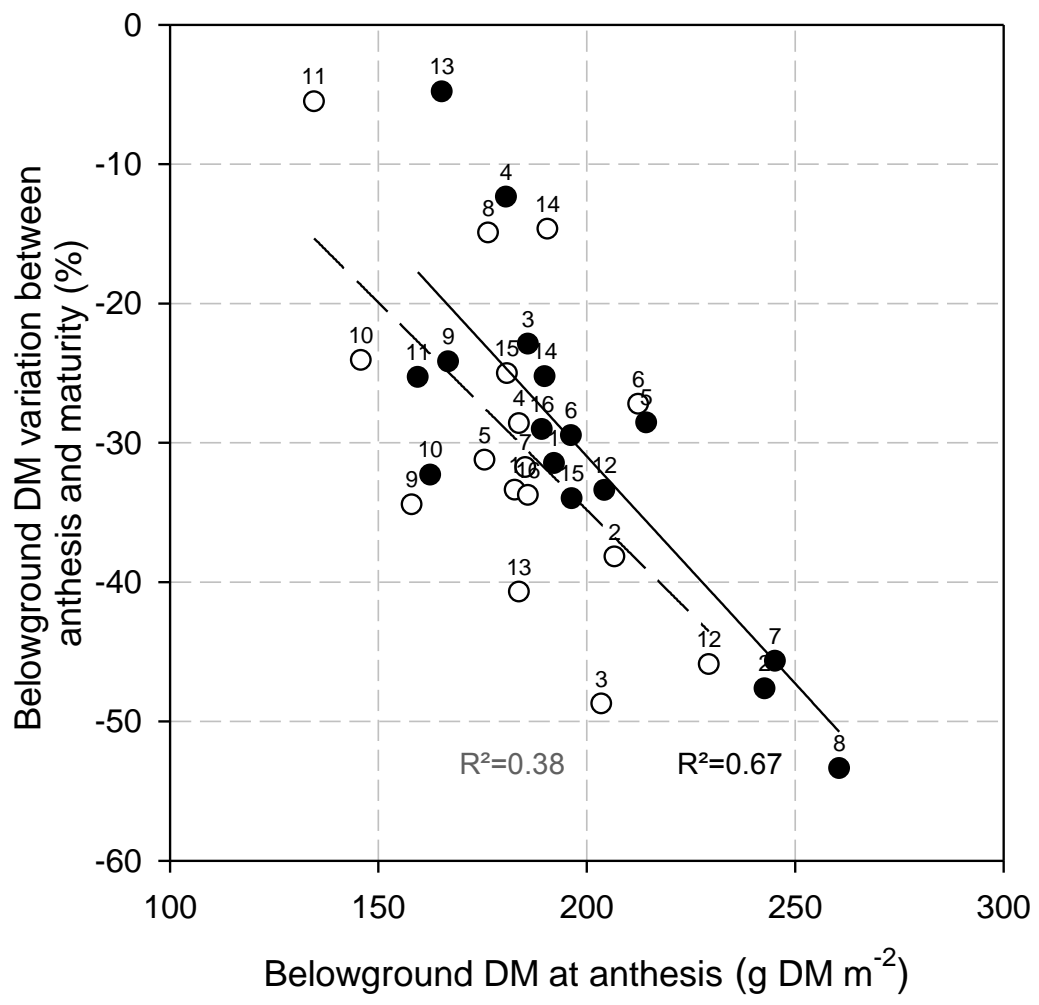

581

$582 \quad$ Figure 4

583

584 
Tables

Table 1: Soil characteristics at the Clermont-Ferrand site

Previous crop

barley

Soil textural class (USDA system)

clay loam

Soil particle size distribution (\% of soil dry mass)

$\begin{array}{ll}\text { Stone }(>2.0 \mathrm{~mm}) & <2 \\ \text { Sand }(0.05-2.0 \mathrm{~mm}) & 19.8\end{array}$

Silt $(0.002-0.05 \mathrm{~m}) \quad 36.7$

Clay $(<0.002 \mathrm{~mm}) \quad 43.5$

Maximum rooting depth (m)

0.9

Plant available soil water content (mm)

Apparent bulk density $\left(\mathrm{t} \mathrm{m}^{-3}\right)$

1.15

Organic matter $(\%)$

$\mathrm{pH}$ in water

8.1

Inorganic soil $\mathrm{N}(0-90 \mathrm{~cm}$ layer $)$

6.2

at the end of winter $\left(\mathrm{g} \mathrm{N} \mathrm{m}^{-2}\right)$ 
Table 2: Anthesis date, root dry mass (RDM), shoot dry mass (SDM) and grain dry mass (GDM) at anthesis and grain maturity. Data are means of three replicates. Means for the LN and $\mathrm{HN}$ treatments are calculated. $\mathrm{P}$ values were obtained with a split plot ANOVA.

\begin{tabular}{|c|c|c|c|c|c|c|c|c|}
\hline \multirow[b]{2}{*}{ Treatment } & \multicolumn{2}{|c|}{ Genotype } & \multicolumn{3}{|c|}{ Anthesis } & \multicolumn{3}{|c|}{ Maturity } \\
\hline & Name & Code & $\begin{array}{c}\text { Anthesis } \\
\text { Date }\end{array}$ & $\begin{array}{c}\text { RDM } \\
\mathrm{g} \mathrm{DM} \mathrm{m}^{-2}\end{array}$ & $\begin{array}{c}\text { SDM } \\
\text { g DM m }^{-2}\end{array}$ & $\begin{array}{c}\text { RDM } \\
\mathrm{g} \mathrm{DM} \mathrm{m}^{-2}\end{array}$ & $\begin{array}{c}\text { SDM } \\
\mathrm{g} \mathrm{DM} \mathrm{m}^{-2}\end{array}$ & $\begin{array}{c}\text { GDM } \\
\text { g DM m }^{-2}\end{array}$ \\
\hline \multirow{16}{*}{$\mathrm{LN}$} & Alchemy & 1 & $03 / 06 / 08$ & 183 & 750 & 122 & 1118 & 499 \\
\hline & Beaver & 2 & $04 / 06 / 08$ & 207 & 799 & 128 & 1278 & 590 \\
\hline & Consort & 3 & $04 / 06 / 08$ & 203 & 756 & 104 & 1037 & 493 \\
\hline & Paragon & 4 & $02 / 06 / 08$ & 184 & 845 & 131 & 1152 & 482 \\
\hline & Rialto & 5 & $30 / 05 / 08$ & 176 & 697 & 121 & 1054 & 480 \\
\hline & Robigus & 6 & 02/06/08 & 212 & 735 & 155 & 1327 & 618 \\
\hline & Savannah & 7 & 03/06/08 & 185 & 816 & 126 & 1234 & 592 \\
\hline & Soissons & 8 & $20 / 05 / 08$ & 176 & 890 & 150 & 1066 & 479 \\
\hline & Arche & 9 & $26 / 05 / 08$ & 158 & 906 & 104 & 1411 & 680 \\
\hline & CF9107 & 10 & $22 / 05 / 08$ & 146 & 795 & 111 & 1099 & 516 \\
\hline & CF99102 & 11 & $26 / 05 / 08$ & 135 & 725 & 127 & 1377 & 624 \\
\hline & Perfector & 12 & $28 / 05 / 08$ & 229 & 773 & 124 & 1248 & 595 \\
\hline & Quebon & 13 & $29 / 05 / 08$ & 184 & 788 & 109 & 1344 & 583 \\
\hline & Récital & 14 & $19 / 05 / 08$ & 191 & 962 & 163 & 1074 & 464 \\
\hline & Renan & 15 & $21 / 05 / 08$ & 181 & 1039 & 136 & 1260 & 505 \\
\hline & Toisondor & 16 & $27 / 05 / 08$ & 186 & 789 & 123 & 1331 & 649 \\
\hline \multirow[t]{8}{*}{ Mean $L N$} & & & & 184 & 817 & 127 & 1213 & 553 \\
\hline & Alchemy & 1 & 03/06/08 & 192 & 924 & 132 & 1422 & 633 \\
\hline & Beaver & 2 & $04 / 06 / 08$ & 243 & 1026 & 127 & 1719 & 803 \\
\hline & Consort & 3 & 04/06/08 & 186 & 1040 & 143 & 1750 & 846 \\
\hline & Paragon & 4 & $02 / 06 / 08$ & 181 & 957 & 158 & 1736 & 702 \\
\hline & Rialto & 5 & $30 / 05 / 08$ & 214 & 868 & 153 & 1543 & 730 \\
\hline & Robigus & 6 & $02 / 06 / 08$ & 196 & 925 & 138 & 1883 & 898 \\
\hline & Savannah & 7 & 03/06/08 & 245 & 956 & 133 & 1705 & 797 \\
\hline \multirow{9}{*}{$\mathrm{HN}$} & Soissons & 8 & $20 / 05 / 08$ & 261 & 961 & 122 & 1491 & 746 \\
\hline & Arche & 9 & $26 / 05 / 08$ & 167 & 875 & 126 & 1704 & 787 \\
\hline & CF9107 & 10 & $22 / 05 / 08$ & 162 & 984 & 110 & 1435 & 734 \\
\hline & CF99102 & 11 & $26 / 05 / 08$ & 159 & 920 & 119 & 1666 & 794 \\
\hline & Perfector & 12 & $28 / 05 / 08$ & 204 & 971 & 136 & 1827 & 847 \\
\hline & Quebon & 13 & $29 / 05 / 08$ & 165 & 958 & 157 & 1638 & 739 \\
\hline & Récital & 14 & $19 / 05 / 08$ & 190 & 1003 & 142 & 1270 & 614 \\
\hline & Renan & 15 & $21 / 05 / 08$ & 196 & 1069 & 130 & 1581 & 708 \\
\hline & Toisondor & 16 & $27 / 05 / 08$ & 189 & 975 & 134 & 1679 & 812 \\
\hline Mean HN & & & & 197 & 963 & 135 & 1628 & 762 \\
\hline \multirow{3}{*}{$\begin{array}{l}\text { Source of } \\
\text { variance }\end{array}$} & Treatment & & & 0.248 & $0.005^{* *}$ & 0.123 & $0.019^{*}$ & $0.014 *$ \\
\hline & Genotype & & & $0.001 * *$ & $0.019^{*}$ & 0.397 & $0.010^{*}$ & $<0.001 * * *$ \\
\hline & TxG & & & 0.251 & 0.425 & 0.464 & 0.865 & 0.886 \\
\hline
\end{tabular}


Table 3: root $\mathrm{N}$ amount (RN), root $\mathrm{N}$ concentration (RN\%) at anthesis and grain maturity. Calculated variables are nitrogen harvest index based on shoot $\mathrm{N}$ only (NHI) or total plant $\mathrm{N}$ $\left(\mathrm{NHI}_{\text {tot }}\right), \mathrm{N}$ utilization efficiency based on shoot $\mathrm{N}$ only $(\mathrm{NUtE})$ or total plant $\mathrm{N}$ ( $\left.\mathrm{NUtE}_{\text {tot }}\right), \mathrm{N}$ lost from root between anthesis and maturity (NLR), N potentially remobilized by roots assuming $0.3 \% \mathrm{~N}$ in the dead roots $\left(\mathrm{NRR}_{0.3}\right)$ and the proportion of grain $\mathrm{N}$ originating from roots (PGNR). Data are means of three replicates. Means for the LN and HN treatments are calculated. $\mathrm{P}$ values were obtained with a split plot ANOVA.

\begin{tabular}{|c|c|c|c|c|c|c|c|c|c|c|c|c|}
\hline \multirow[b]{2}{*}{ Tretment } & \multirow[b]{2}{*}{$\begin{array}{c}\text { Genotype } \\
\text { code }\end{array}$} & \multicolumn{2}{|c|}{ Anthesis } & \multicolumn{2}{|c|}{ Maturity } & \multicolumn{7}{|c|}{ Calculations } \\
\hline & & $\begin{array}{c}\mathrm{RN} \\
\mathrm{g} \mathrm{N} \mathrm{m}^{-2}\end{array}$ & $\begin{array}{l}\mathrm{RN} \% \\
\% \mathrm{DM}\end{array}$ & $\begin{array}{c}\mathrm{RN} \\
\mathrm{g} \mathrm{N} \mathrm{m}^{-2}\end{array}$ & $\begin{array}{l}\mathrm{RN} \% \\
\% \mathrm{DM}\end{array}$ & NHI & $\mathrm{NHI}_{\mathrm{tot}}$ & $\begin{array}{l}\text { NUtE } \\
\text { gDM }\end{array}$ & $\begin{array}{l}\mathrm{NUtE} \\
\mathrm{gN}^{-1}\end{array}$ & $\begin{array}{r}\text { NLR } \\
\text { g I }\end{array}$ & $\begin{array}{l}\mathrm{NRR}_{0.3} \\
\mathrm{~m}^{-2}\end{array}$ & $\begin{array}{c}\text { PGNR } \\
\%\end{array}$ \\
\hline \multirow{16}{*}{ LN } & 1 & 0.7 & 0.39 & 0.5 & 0.39 & 76.5 & 73.2 & 47.8 & 45.8 & 0.24 & 0.05 & 0.6 \\
\hline & 2 & 0.9 & 0.43 & 0.6 & 0.43 & 78.6 & 75.3 & 45.8 & 43.9 & 0.33 & 0.09 & 0.9 \\
\hline & 3 & 0.7 & 0.35 & 0.4 & 0.41 & 76.2 & 73.2 & 47.7 & 45.8 & 0.34 & 0.00 & 0.0 \\
\hline & 4 & 0.7 & 0.40 & 0.5 & 0.41 & 82.0 & 77.8 & 48.2 & 45.8 & 0.20 & 0.04 & 0.5 \\
\hline & 5 & 0.8 & 0.45 & 0.5 & 0.43 & 79.9 & 76.1 & 45.5 & 43.3 & 0.27 & 0.10 & 1.2 \\
\hline & 6 & 0.8 & 0.38 & 0.6 & 0.39 & 76.6 & 73.0 & 49.5 & 47.2 & 0.20 & 0.02 & 0.2 \\
\hline & 7 & 0.8 & 0.43 & 0.6 & 0.45 & 79.1 & 76.1 & 41.7 & 40.0 & 0.21 & 0.08 & 0.7 \\
\hline & 8 & 0.8 & 0.48 & 0.7 & 0.50 & 81.0 & 75.4 & 48.2 & 44.9 & 0.10 & 0.07 & 0.9 \\
\hline & 9 & 0.6 & 0.38 & 0.4 & 0.37 & 80.8 & 78.5 & 51.1 & 49.7 & 0.21 & 0.07 & 0.7 \\
\hline & 10 & 0.7 & 0.45 & 0.5 & 0.41 & 80.6 & 77.2 & 49.5 & 47.4 & 0.20 & 0.09 & 1.1 \\
\hline & 11 & 0.6 & 0.46 & 0.5 & 0.40 & 83.0 & 80.1 & 43.6 & 42.1 & 0.08 & 0.05 & 0.5 \\
\hline & 12 & 0.9 & 0.37 & 0.6 & 0.49 & 76.5 & 73.1 & 46.1 & 44.0 & 0.24 & 0.02 & 0.2 \\
\hline & 13 & 0.8 & 0.41 & 0.4 & 0.40 & 77.8 & 75.4 & 41.4 & 40.2 & 0.31 & 0.09 & 0.8 \\
\hline & 14 & 0.8 & 0.42 & 0.8 & 0.47 & 77.6 & 71.7 & 49.2 & 45.5 & -0.24 & 0.04 & 0.7 \\
\hline & 15 & 0.8 & 0.47 & 0.5 & 0.36 & 76.9 & 74.1 & 40.5 & 39.0 & 0.37 & 0.23 & 2.4 \\
\hline & 16 & 0.8 & 0.43 & 0.4 & 0.34 & 80.8 & 78.3 & 50.2 & 48.7 & 0.38 & 0.19 & 1.9 \\
\hline \multirow{9}{*}{$\begin{array}{c}\text { Mean } \\
L N\end{array}$} & & 0.76 & 0.42 & 0.53 & 0.42 & 79 & 75.5 & 46.6 & 44.6 & 0.22 & 0.08 & 0.83 \\
\hline & & & & & & & & & & & & \\
\hline & 1 & 1.5 & 0.78 & 1.0 & 0.74 & 66.8 & 63.6 & 31.6 & 30.1 & 0.56 & 0.38 & 5.6 \\
\hline & 2 & 2.4 & 0.99 & 1.0 & 0.85 & 69.3 & 66.6 & 31.2 & 30 & 1.35 & 1.00 & 2.6 \\
\hline & 3 & 1.7 & 0.90 & 1.1 & 0.76 & 69.9 & 67.2 & 32.1 & 30.9 & 0.59 & 0.46 & 0.8 \\
\hline & 4 & 1.4 & 0.80 & 1.3 & 0.82 & 69.0 & 65.4 & 28.2 & 26.7 & 0.15 & 0.15 & 5.1 \\
\hline & 5 & 2.0 & 0.94 & 1.0 & 0.67 & 74.1 & 70.8 & 32.3 & 30.9 & 1.00 & 0.81 & 2.6 \\
\hline & 6 & 1.6 & 0.83 & 1.0 & 0.72 & 69.5 & 66.8 & 34.6 & 33.2 & 0.64 & 0.47 & 2.4 \\
\hline & 7 & 2.0 & 0.84 & 1.3 & 0.97 & 65.5 & 62.3 & 31.1 & 29.5 & 0.77 & 0.45 & 3.3 \\
\hline \multirow{9}{*}{$\mathrm{HN}$} & 8 & 2.0 & 0.75 & 1.0 & 0.80 & 75.9 & 72.7 & 33.9 & 32.5 & 0.99 & 0.57 & 1.7 \\
\hline & 9 & 1.3 & 0.78 & 0.9 & 0.72 & 76.1 & 73.0 & 36.4 & 35.0 & 0.39 & 0.27 & 1.7 \\
\hline & 10 & 1.3 & 0.80 & 0.9 & 0.81 & 76.9 & 74.0 & 32.9 & 31.6 & 0.41 & 0.29 & 0.6 \\
\hline & 11 & 1.3 & 0.78 & 1.0 & 0.86 & 78.2 & 75.1 & 32.6 & 31.3 & 0.24 & 0.11 & 1.7 \\
\hline & 12 & 1.6 & 0.78 & 1.1 & 0.82 & 68.6 & 65.8 & 31.7 & 30.4 & 0.46 & 0.32 & 2.0 \\
\hline & 13 & 1.5 & 0.90 & 1.1 & 0.68 & 73.6 & 70.5 & 30.1 & 28.8 & 0.36 & 0.34 & 1.9 \\
\hline & 14 & 1.6 & 0.86 & 1.4 & 0.99 & 70.4 & 65.4 & 32.6 & 30.3 & 0.26 & 0.26 & 2.3 \\
\hline & 15 & 1.5 & 0.76 & 0.9 & 0.70 & 72.5 & 69.9 & 28.2 & 27.2 & 0.57 & 0.39 & 1.9 \\
\hline & 16 & 1.5 & 0.77 & 1.0 & 0.72 & 73.1 & 70.2 & 34.4 & 33 & 0.5 & 0.34 & 0 \\
\hline $\begin{array}{c}\text { Mean } \\
H N\end{array}$ & & 1.64 & 0.83 & 1.06 & 0.79 & 71.8 & 68.7 & 32.1 & 30.7 & 0.58 & 0.41 & 2.26 \\
\hline Source & $\mathrm{N}$ & $0.002 * *$ & $<0.001 * * *$ & $0.008 * *$ & $0.004 * *$ & $0.006^{* * *}$ & $0.005^{* *}$ & $0.003^{* *}$ & $0.002 * *$ & $0.031^{*}$ & $0.025^{*}$ & $0.041^{*}$ \\
\hline of & G & $<0.001 * * *$ & 0.207 & $0.027 *$ & $0.019 *$ & $<0.001 * * *$ & $<0.001 * * *$ & $<0.001 * * *$ & $<0.001 * * *$ & $0.022^{*}$ & $0.049^{*}$ & $0.036^{*}$ \\
\hline variance & $\mathrm{TxG}$ & 0.052 & 0.082 & 0.794 & 0.637 & 0.075 & $0.041 *$ & 0.332 & 0.350 & 0.245 & 0.097 & 0.110 \\
\hline
\end{tabular}

